\title{
Trophic State EVAluation OF JACKSON LAKE in GRaNd Teton National Park
}

\author{
WOODRUFF MILLER $\downarrow$ CIVIL ENGINEERING DEPARTMENT \\ BRIGHAM YOUNG UNIVERSITY $\downarrow$ PROVO $\downarrow$ UT
}

\section{$\downarrow \quad$ INTRODUCTION}

This study is the continuation of an evaluation of the trophic state of lakes located in Grand Teton National Park, Wyoming. The original 1995 study was motivated by concern that the water quality of the lakes within the Park may be declining due to increased human usage over the past several years. A trophic state evaluation, featuring nutrient and chlorophyll-a analyses, was chosen because it is believed to be a sound indicator of the lakes' overall water quality. In this 1996 study, a thorough evaluation was made of Jackson Lake. This summary is taken from the complete 100 page report which is available from Woodruff Miller at Brigham Young University or Hank Harlow at the University of Wyoming.

In most cases water samples were taken four times during the summer of 1996, in June, July, August, and October. Jackson Lake was sampled at eight different locations on the surface and at depths near the bottom. The lake inlet and outlet were also sampled four times. Jackson Lake was sampled from a motor boat which also provided a means to measure the lake transparency and depth. The chlorophyll-a and nutrient concentrations were analyzed by the Utah State Health Department, Division of Laboratory Services.

Jackson Lake was evaluated using the models of Carlson, Vollenweider, and Larsen-
Mercier. The nature of the Larsen-Mercier and Vollenweider models, based on system inflow and outflow data, is such that they yield one trophic state assessment of the lake per inflow and outflow sample set. The Carlson Trophic State Indices (TSI), on the other hand, are based on in situ properties of the water at any point in the lake. Consequently, while there are four Vollenweider and four Larsen-Mercier evaluations for Jackson Lake, individual Carlson evaluations were made for the eight sample sites around the lake at the surface and at depth, and an evaluation for the lake as a whole was constructed using averages taken from the site evaluations. This allowed us to examine the relative water quality of different portions of the lake at different time periods.

\section{Jackson Lake, Carlson Model}

The Carlson model indicates good water quality for Jackson Lake. An overall TSI was determined by taking the average for all the sample sites. This resulted in a TSI of $\mathbf{3 8}$ for the overall lake average as shown in Table 1. Jackson Lake was consequently rated slightly mesotrophic according to the Carlson model. Most of the Carlson TSI results for the sample sites on Jackson Lake were in the range of 30 to 40 , in the oligotrophic to slightly mesotrophic classification.

However, site 8 is different, and is discussed in more detail below. 


\begin{tabular}{|c|c|c|c|c|c|c|c|}
\hline \multirow[t]{2}{*}{ Month } & \multicolumn{2}{|c|}{$\begin{array}{c}\text { Total } \\
\text { Phosphorus }\end{array}$} & \multicolumn{2}{|c|}{ Chlorophyll-a } & \multicolumn{2}{|c|}{ Transparency } & \multirow[t]{2}{*}{$\begin{array}{l}\text { Average } \\
\text { TSI }\end{array}$} \\
\hline & ppb & TSI & $\mathrm{ppb}$ & TSI & $\mathbf{m}$ & TSI & \\
\hline June & 49.8 & 52.6 & 2.1 & 34.8 & 2.7 & 46.7 & 44.7 \\
\hline July & 31.7 & 44.5 & 2.6 & 34.7 & 3.1 & 43.5 & 40.9 \\
\hline August & 10.7 & 38.7 & 1.2 & 31.0 & 4.9 & 37.3 & 35.7 \\
\hline October & 11.3 & 38.3 & 0.6 & 25.2 & 6.3 & 33.7 & 32.4 \\
\hline $\begin{array}{l}\text { Lake average for } \\
\text { sampling period }\end{array}$ & 25.9 & 43.5 & 1.6 & 31.4 & 4.3 & 40.3 & 38.4 \\
\hline
\end{tabular}

Sample site 8 is located in East Spalding Bay off of South Landing on the southeast side of Jackson Lake. East Spalding Bay is of particular concern in this study due to its proximity to sewage disposal ponds located approximately $1 / 4$ mile east of the bay. Samples were taken at the surface and at a depth of 22 meters on June 4, July 20, August 16, and October 5 (Table 2).

The overall average TSI values indicated in Table 2 are 37.3 at the surface and 48.4 at 22 meters. The Carlson TSIs shown in Figures 1 and 2 indicate a slightly mesotrophic condition at the surface, and a strongly mesotrophic condition at depth, which is a concern. In June, phosphorus content was in the hyper-eutrophic range at $140 \mathrm{ppb}$, and in July it was off of the Carlson scale at 250 ppb. Chlorophyll and transparency, were both within reasonable (mesotrophic) limits, but were also high in June and July in comparison with other sites around the lake. When samples were taken in August and October, however, water quality was

\begin{tabular}{|c|c|c|c|c|c|c|c|c|}
\hline \multirow[t]{2}{*}{$\begin{array}{l}\text { Sample } \\
\text { Depth }\end{array}$} & \multirow[t]{2}{*}{ Date } & \multicolumn{2}{|c|}{$\begin{array}{c}\text { Total } \\
\text { Phosphorus }\end{array}$} & \multicolumn{2}{|c|}{ Chlorophyll-a } & \multicolumn{2}{|c|}{ Transparency } & \multirow[t]{2}{*}{$\begin{array}{c}\text { Average } \\
\text { TSI }\end{array}$} \\
\hline & & $\mathrm{ppb}$ & TSI & $\mathrm{ppb}$ & TSI & $\mathrm{m}$ & TSI & \\
\hline \multirow[t]{5}{*}{ Surface } & 5-Jun-96 & 110 & 72 & 0.5 & 24 & 4.5 & 38 & 44.7 \\
\hline & 20-Jul-96 & 10 & 38 & 1.4 & 36 & 3.5 & 41 & 38.3 \\
\hline & 16-Aug-96 & 10 & 38 & 0.7 & 28 & 4.5 & 38 & 34.7 \\
\hline & $5-$-Oct-96 & 10 & 38 & 0.4 & 21 & 5.5 & 35 & 31.3 \\
\hline & Average & 35.0 & 46.5 & 0.75 & 27.3 & 4.5 & 38.0 & 37.3 \\
\hline \multirow[t]{5}{*}{$22 \mathrm{~m}$} & 5-Jun-96 & 140 & 75 & 3.4 & 43 & 4.5 & 38 & 52.0 \\
\hline & 20-Jul-96 & 250 & 100 & 5.5 & 48 & 3.5 & 41 & 63.0 \\
\hline & 16-Aug-96 & 10 & 38 & 3.9 & 44 & 4.5 & 38 & 40.0 \\
\hline & 5-Oct-96 & 23 & 50 & 1.0 & 31 & 5.5 & 35 & 38.7 \\
\hline & Average & 106 & 65.8 & 3.5 & 41.5 & 4.5 & 38.0 & 48.4 \\
\hline
\end{tabular}




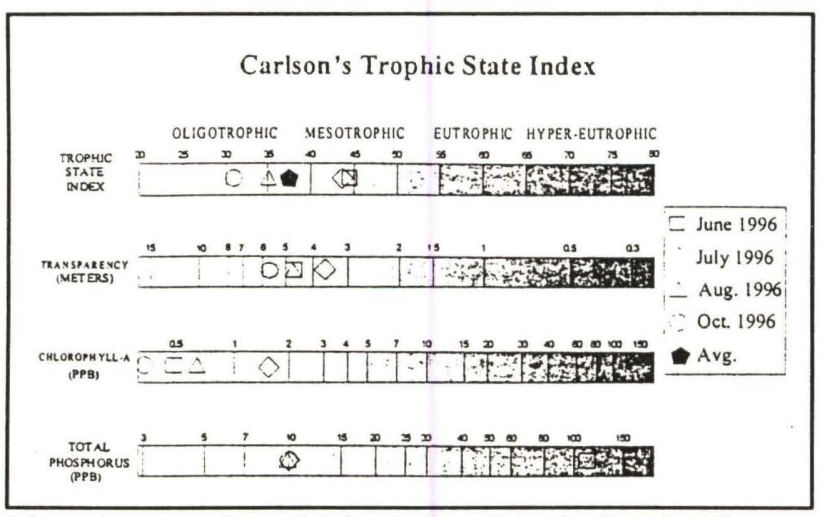

Figure 1. Carlson's model for Jackson Lake in East Spalding Bay off of South Landing at the surface (sample site 8)

comparable to the rest of Jackson Lake, having shifted to the slightly mesotrophic range. Overall, East Spalding Bay is regarded as mesotrophic.

These results in East Spalding Bay raise several questions. First, where did the phosphorus come from? Is it part of a seasonal cycle coinciding with high spring run off? Is it a product of seepage from the sewage disposal ponds? Or, does it come from an as yet unconsidered source? Further, is the phosphorus a function of depth, as seems apparent from the data? Finally, what happened to the phosphorus after July? Was it flushed through the outlet, or mixed through the lake and utilized? Further studies are needed to answer these questions.

\section{Jackson Lake, Vollenweider Model}

The Vollenweider Model is shown in Figure 3. According to this model, the July and August data classify the lake as oligotrophic, and October as slightly mesotrophic. The June data gives the greatest cause for concern, with inflow phosphorus concentrations pushing the lake's condition into the hyper-eutrophic range. Inflow phosphorus in June was measured at $260 \mu \mathrm{g} / \mathrm{l}$, an order of magnitude higher than the values recorded through the rest of the summer (Table 3). The June data were given less weight in assessing the average Vollenweider trophic state for Jackson Lake because primary productivity data collected for the Carlson model (i.e. transparency, chlorophyll, and in-lake phosphorus) did not correspond with the high inflow phosphorus level in June (Table 3). Jackson Lake was determined to be slightly mesotrophic by the Vollenweider model.

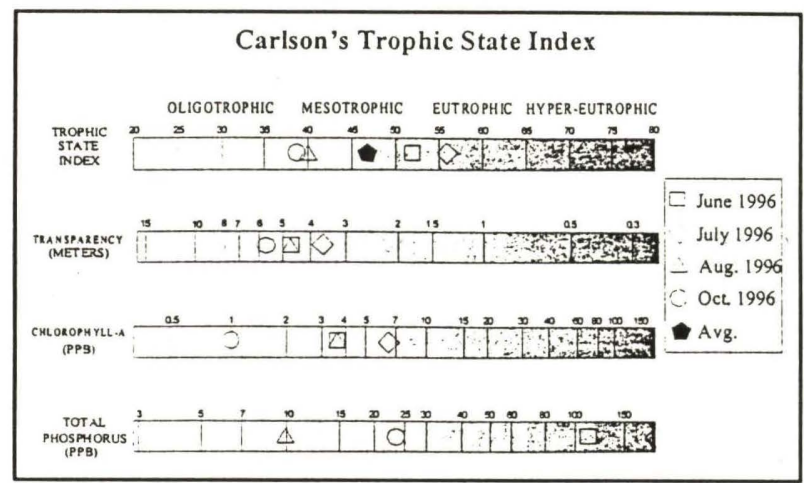

Figure 2. Carlson's model for Jackson Lake in East Spalding Bay off of South Landing at $22 \mathrm{~m}$ (samle site 8 )

$\underline{\text { Jackson Lake, Larsen-Mercier Model }}$

The Larsen-Mercier model is generally considered to best indicate the trophic state of lakes with a maximum hydraulic residence time of 6 months but Jackson Lake's residence time is approximately 2 years. In spite of this, the LarsenMercier model shown in Figure 4 yielded a trophic state evaluation for Jackson Lake that corresponded very well with the Vollenweider and Carlson models. High phosphorus concentrations at the inflow (Table 3) caused June's data to yield a slightly mesotrophic state for the lake. When coupled with slightly oligotrophic states in July and August, and a strongly mesotrophic state in October, the overall Larsen-Mercier indication for Jackson Lake was slightly mesotrophic.

Jackson Lake Temperature and Dissolved Oxygen Profiles

Temperature and dissolved oxygen (D.O.) profiles were compiled for each of the eight sample sites in June, August, and October of 1996. All these measurements are displayed in the complete 100 page report. Figure 5 shows average lake temperatures over the summer, and Figure 6 shows average lake dissolved oxygen over the same period. The temperature profiles seem to indicate a fairly well mixed lake in June, and thermoclines at about $4-12 \mathrm{~m}$ in August, and at about $8-11 \mathrm{~m}$ in October. D.O. profiles show the oxygen content of the lake decreasing between June and August, and increasing again in October. 


\begin{tabular}{|c|c|c|c|c|}
\hline Table 3: Inflow Total Phosphorus Compared to Indicators of Productivity \\
\hline \hline & $\begin{array}{c}\text { Inflow Total } \\
\text { Phosphorus } \\
(\mathrm{ug} / \mathrm{l})\end{array}$ & $\begin{array}{c}\text { Chlorophyll-a } \\
(\mathrm{ppb})\end{array}$ & $\begin{array}{c}\text { Transparency } \\
(\mathrm{m})\end{array}$ & $\begin{array}{c}\text { In-lake Total } \\
\text { Phosphorus } \\
(\mathrm{mg} / \mathrm{l})\end{array}$ \\
\hline June & 260 & 2.1 & 2.7 & 49.8 \\
\hline July & 10 & 2.6 & 3.1 & 31.7 \\
\hline August & 10 & 1.2 & 4.9 & 10.7 \\
\hline October & 26 & 0.6 & 6.3 & 11.3 \\
\hline
\end{tabular}

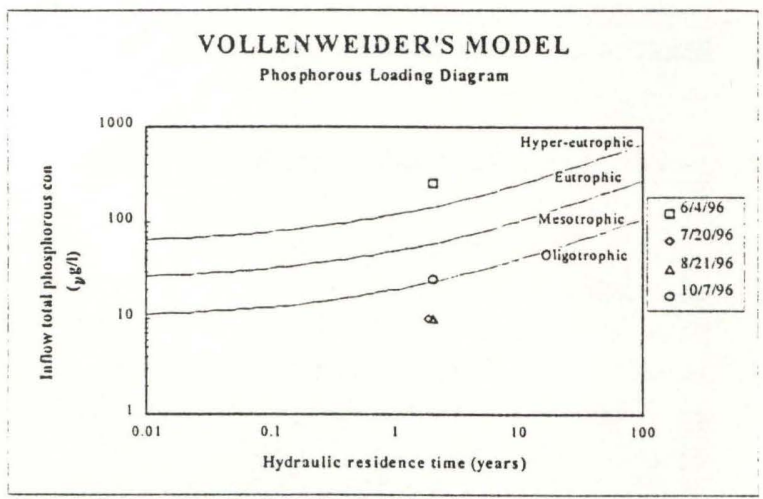

Figure 3: Vollenweider's Model for Jackson Lake

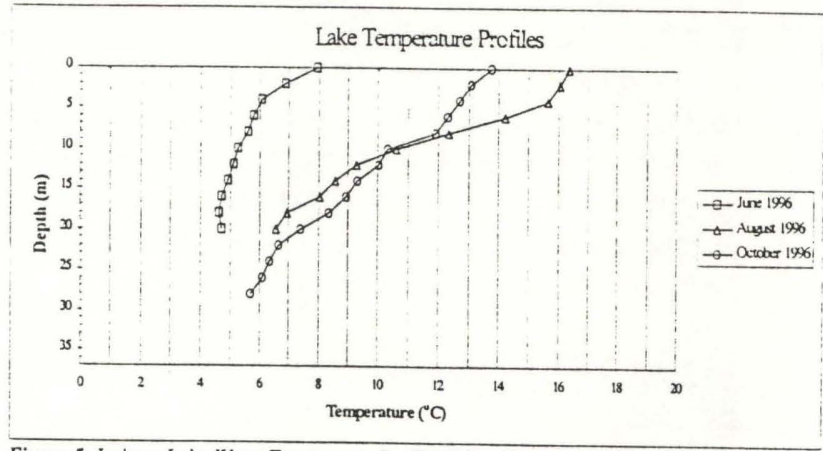

Figure 5: Jackson Lake Water Temperature Profiles; Monthly Averages June-October 1996

\section{Jackson Lake Nitrogen Phosphorus Ratios}

Total nitrogen and phosphorus measurements were taken in East Spalding Bay and from the lake near Waterfall Canyon in June, July, and August (Table 5). The literature suggests that when the N:P ratio is less than approximately 7.2, the system is nitrogen limited. These two sites are generally phosphorus limited, but nitrogen was limiting in East Spalding Bay at depth in June and July when phosphorus levels in East Spalding Bay were abnormally high and productivity was relatively low.

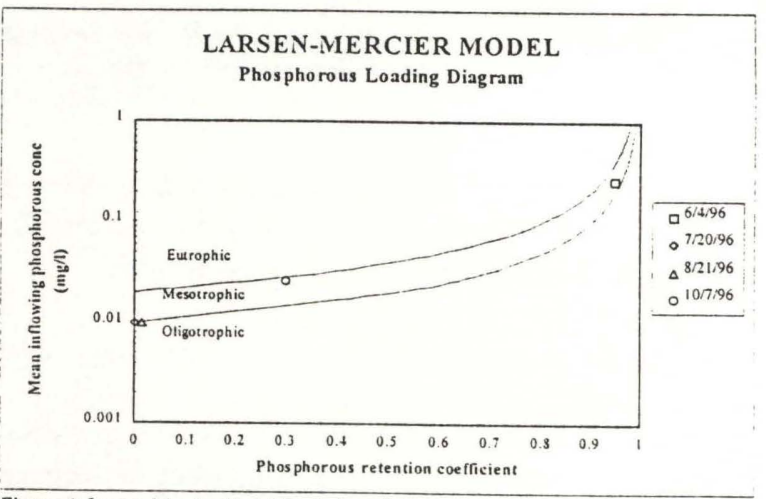

Figure 4: Larsen-Mercier Model for Jackson Lake

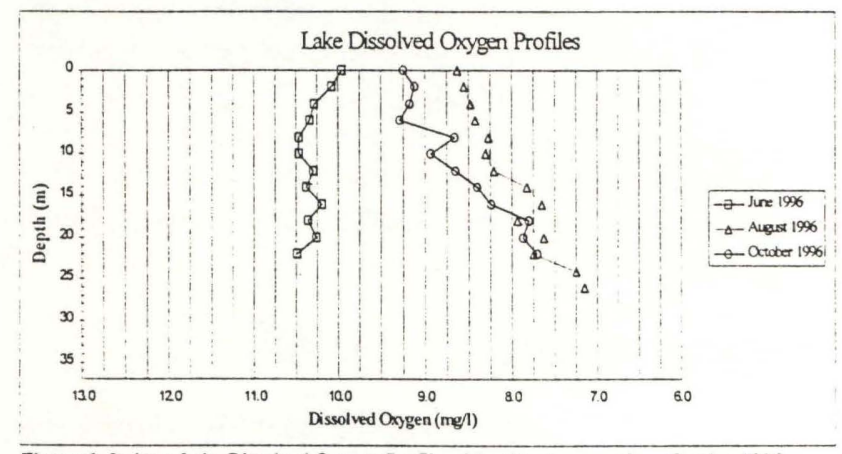

Figure 6: Jackson Lake Dissolved Oxygen Profiles; Monthly Averages June-October 1996

Jackson Lake Specific Conductivity

Specific conductivity is a parameter which can be used to compare quality among all water samples at any temperature. The specific conductivities for Jackson Lake were all very similar, with an average value of $148 \mathrm{uS} / \mathrm{cm}$ and a range of 128 to 167 . This indicates high water quality in terms of dissolved mineral content. The common parameter to measure the dissolved salts in water is TDS (Total Dissolved Salts). TDS is usually about 60 to $80 \%$ of the specific conductivity. This approximation would suggest an average TDS for Jackson Lake at about 100ppm which indicates high quality water. 


\begin{tabular}{|c|c|c|c|c|c|c|}
\hline \multicolumn{2}{|c|}{ Table 5: Nitrogen Phosphorus Ratio in East Spalding Bay and off Waterfall Canyon } \\
\hline \hline & Date & Depth & $\begin{array}{c}\text { Total } \\
\text { Nitrogen } \\
(\mathrm{mg} / \mathrm{l})\end{array}$ & $\begin{array}{c}\text { Total } \\
\text { Phos. } \\
(\mathrm{mg} / \mathrm{l})\end{array}$ & $\begin{array}{c}\text { N:P Ratio } \\
\text { (If N:P > 7.2, } \\
\text { Phos. is limiting) }\end{array}$ & $\begin{array}{c}\text { Limiting } \\
\text { Nutrient }\end{array}$ \\
\hline $\begin{array}{c}\text { East Spalding } \\
\text { Bay }\end{array}$ & 5-Jun & 22 & 0.107 & 0.14 & 0.76 & Nitrogen \\
\hline & 20-Jul & 22 & 0.285 & 0.25 & 1.14 & Nitrogen \\
\hline & 16-Aug & 0 & 0.258 & 0.01 & 26 & Phosphorus \\
\hline & 16-Aug & 22 & 0.44 & 0.01 & 44 & Phosphorus \\
\hline $\begin{array}{c}\text { Off Waterfall } \\
\text { Canyon }\end{array}$ & 5-Jun & 50 & 0.295 & 0.01 & 30 & Phosphorus \\
\hline & 20-Jul & 50 & 0.7 & 0.01 & 70 & Phosphorus \\
\hline & 16-Aug & 50 & 0.51 & 0.01 & 51 & Phosphorus \\
\hline
\end{tabular}

